\title{
Kontribusi Syaikh Hasan Maksum dalam Bidang Pendidikan di Sumatera Utara
}

\author{
Muhammad Rozali \\ Dosen di Universitas Islam Negeri Sumatera Utara dan Universitas \\ Dharmawangsa Medan
}

\begin{abstract}
Abstrak
Artikel ini membahas mengenai seorang ulama kharismatik dari Deli bernama Hasanuddin bin Muhammad Maksum bin Abu Bakar gelar Imam Paduka Tuan atau lebih dikenal dengan nama Hasan Maksum (1884-1936) dan kontribusinya dalam dunia pendidikan Islam di Sumatera Utara. Keulamaan Hasan Maksum tidak bisa dipisahkan dari organisasi besar Islam seperti Al Jam'iyatul Washliyah dan juga kontribusinya yang sangat besar bagi perkembangan tradisi keulamaan di Sumatera Utara. Selama 20 tahun ia belajar ilmu-ilmu agama Islam di Makkah kepada ulama-ulama besar di sana, termasuk kepada Syaikh Ahmad Khatib al-Minangkabawi. Di Deli, ia aktif mengajar di sejumlah masjid dan langgar dan murid-muridnya kemudian menjadi ulama terkemuka di Sumatera Utara. Selain sebagai ulama dan guru yang dikenal sangat zuhud dan sederhana, ia juga pernah diangkat sebagai Mufti Kesultanan Deli hingga akhir hayatnya.

Keywords: Hasan Maksum, Pendidikan Islam, Ulama Sumatera Utara.
\end{abstract}

\section{PENDAHULUAN}

Kebangkitkan pendidikan Islam di Indonesia ditandai dengan lahirnya beberapa organisasi Islam, seperti Muhammadiyah (1912) di Yogyakarta, dan diikuti oleh beberapa organisasi lain, seperti Persyarikatan Ulama (1915) di Majalengka, Persatuan Islam (1923) di Bandung, Nahdlatul Ulama (1926) di Surabaya, Al Jam'iyatul Washliyah (1930) ${ }^{1}$ dan Al-Ittihadiyah (1935) di Medan. Dalam sejarah Sumatera Utara menjelang kemerdekaan, ulama Al Jam'iyatul Washliyah adalah orangorang yang sangat menonjol dalam memperjuangkan Islam, baik dalam bidang pendidikan, dakwah, sosial maupun politik.

1 Ahmad Mansur Suryanegara, Menemukan Sejarah Wacana Pergerakan Islam di Indonesia (Bandung: Penerbit Mizan, 1995), h. 216. Al Jam'iyatul Washliyah memiliki badan hukum menurut Penetapan Menteri Kehakiman tanggal 17 Oktober 1959 No: J-A 5/74/25. Al Jam'iyatul Washliyah berarti organisasi yang menghubungkan; antara manusia dengan khaliknya, manusia dengan sesamanya, manusia dengan alamnya, antara organisasi dengan organisasi lain yang seprofessi, antara bangsa Indonesia dengan pemerintah Republik Indonesia, antara umat Islam lokal, nasional dan internasional dan antara umat Islam dengan cita-cita hidupnya. Lihat: M. Ridwan Ibrahim Lubis, Kepribadian Anggota \& Pengurus Al Washliyah (Medan: PP HIMMAH, 1994), hlm. 23. 
Lahir dan berkembangnya Al Jam'iyatul Washliyah di Sumatera Utara memiliki beberapa perbedaan dan persamaan dengan organisasi yang berkembang di luar pulau Jawa. Salah satu perbedaannya adalah $\mathrm{Al}$ Jam'iyatul Washliyah bukanlah organisasi yang bersifat ulama sentris, akan tetapi lebih kepada keumatan. Organisasi ini didirikan oleh sekumpulan ulama terkenal di Sumatera Timur. Sedangkan persamaannya adalah sama-sama memperjuangkan atau membebaskan masyarakat dari kebodohan dan penjajahan.

Seorang tokoh penting yang ikut memperjuangkan kebangkitan organisasi Al Jam'iyatul Washliyah adalah Hasan Maksum. Dengan keikutsertaan beliau dalam membesarkan organisasi ini, masyarakat Sumatara Utara mendapatkan manfaat yang besar. Manfaat itu terus dirasakan dari generasi ke generasi. Jika berbicara mengenai ulama di Sumatera Utara, maka siapa yang tidak mengenal beliau, ulama zuhud dan tidak menyukai popularitas, tidak mengincar jabatan publik, produktif menulis karya-karya akademik dalam berbagai bidang ilmu keislaman, mendidik ulama-ulama berbakat, mendakwahkan Islam melalui organisasi, dan menimba ilmu sampai akhir hidup. ${ }^{2}$

Tulisan yang singkat ini berusaha mengantarkan pembaca untuk mengetahui sejauh mana kontribusi Hasan Maksum dalam Dunia Pendidikan di Sumatera Utara. Walau demikian tulisan ini masih jauh dari kata sempurna, oleh sebab itu berbagai masukan dan kritik diharapkan untuk perbaikan pada masa yang akan datang.

\section{HASIL DAN PEMBAHASAN}

\section{Biografi Keulamaan Hasan Maksum}

Sejarah mencatat bahwa nama Hasan Maksum (1884-1936), tidak bisa dipisahkan dari Al Jam'iyatul Washliyah. Selain peran penting yang dilakoni Maktab Islamiyah Tapanuli, peran Maktab Hasaniyah milik Hasan Maksum juga memberikan kontribusi yang sangat besar bagi perkembangan tradisi keulamaan di Sumatera Utara.

Ulama yang memiliki nama lengkap Hasanuddin bin Muhammad Maksum bin Abu Bakar gelar Imam Paduka Tuan, ${ }^{3}$ yang dikenal dengan Hasan Maksum, dilahirkan pada hari Sabtu, 17 Muharram 1301 H/1882 M,4 namun ada juga riwayat yang menyatakan beliau lahir pada tahun

2 Ja'far, "Tarekat dan Gerakan Sosial Keagamaan Shaykh Hasan Maksum”, dalam Teosofi; Jurnal Tasawuf dan Pemikiran Islam, Vol. 5, No. 2, Tahun 2015, h. 283.

3 Matu Mona, Riwajat Penghidoepan Alfadil: Toen Sjech Hasan Ma'soem (Biografi Sedjak Ketjil Sampai Wafatnja) (Medan: Sjarikat Tapanoeli Medan, t.t.), h. 5.

4 Ibid., hlm. 7. 
$1302 \mathrm{H}$ di Labuhan Deli. ${ }^{5}$ Dari gelar yang disandangnya menunjukkan bahwa beliau adalah bukan orang sembarangan dan memiliki sebuah kedudukan dalam pemerintahan Kesultanan Deli ketika itu. Gelar 'Imam' menunjukkan bahwa beliau adalah merupakan tokoh yang diikuti perkataan dan perbuatannya. Sultan Makmum al-Rasyid, memberikan gelar kehormatan ini karena mengangkat Hasan Maksum sebagai Ulama Kesultanan Deli. Pada awalnya tawaran dari Sultan Deli ini ditolaknya karena beranggapan bahwa dengan menerima gaji dari suatu jabatan maka akan berkurang kebebasannya dalam mengajarkan agama, tapi pada akhirnya tawaran itu diterima, karena pertimbangan bahwa Deli khususnya, Sumatera Timur ketika itu memerlukan seorang ulama yang akan menjadi benteng agama. ${ }^{6}$

Hubungan Hasan Maksum, dengan Al Jam'iyatul Washliyah adalah ibarat hubungan guru dengan murid. Di saat Al Jam'iyatul Washliyah mengalami masa krisis selama dua tahun. Maka diadakan reorganisasi, yang dalam reorganisasi itu diangkatlah Hasan Maksum menjadi penasehat. Al Jam'iyatul Washliyah seakan mendapatkan udara baru, apalagi ketika penduduk Sumatera Timur mengetahui Hasan Maksum sebagai Adviseurnya, dalam waktu yang singkat Al Jam'iyatul Washliyah menjadi popular, berdirilah cabangnya di mana-mana dan madrasahnya tumbuh berkembang. ${ }^{7}$

Pendidikannya dimulai dari keluarganya sendiri, "orang tuanya memiliki peran penting dalam membentuk karakter Hasan Maksum, selain mendapatkan pendidikan formal di sekolah rendah berbahasa Inggris di Labuhan Deli, ${ }^{8}$ dengan seorang guru kebangsaan India dari Malaysia."9 Hasan Maksum, "belajar mengaji dengan orang tuanya tentang Ushuluddin dan lain-lain."10 Keseriusannya dalam pendidikan agama sudah menonjol ketika beliau masih berusia tujuh tahun, "setiap pelajaran dihafalnya sampai tengah malam apalagi segala sesuatu yang berkaitan dengan kisah Rasul SAW."11 Berkat kesungguhan dan kecerdasan dalam menuntut ilmu sehingga beliau mendapat pengakuan

5 Institut Agama Islam Negeri al-Jamiah Sumatera Utara, Sejarah Ulama-Ulama Terkemuka di Sumatera Utara (Medan: Islamyah, 1975), h. 7. Lihat juga: Ahmad bin Hasan Maksum, Biografi Alm. Syech Hasanuddin Maksum (Makalah, tidak diterbitkan), h. 1.

${ }^{6}$ Institut Agama Islam Negeri al-Jamiah Sumatera Utara, Sejarah Ulama, h. 16.

7 Ibid., h. 18.

8 Medan ketika itu merupakan sebuah kampung biasa dan belum memiliki fasilitas transportasi yang memadai. Hal ini jauh berbeda jika dibandingkan dengan Labuhan Deli, merupakan pusat kota yang cukup maju dan telah ramai didatangi oleh para saudagar dari berbagai bangsa. Sehingga di Labuhan Deli berdiri beberapa sekolah dan terdapat juga sekolah Inggris. Lihat: Mona, Riwajat Penghidoepan, hlm. 7.

${ }_{9}$ Maksum, Biografi Alm., h. 1.

10 Mona, Riwajat Penghidoepan, h. 8.

11 Institut Agama Islam Negeri al-Jamiah Sumatera Utara, Sejarah Ulama, h. 8. 
dari gurunya, beliau direkomendasikan agar dimasukkan ke sekolah terbaik. ${ }^{12}$

Kecintaannya terhadap ilmu agama semakin nampak jelas ketika beliau mendapatkan pilihan dari orang tuanya untuk melanjutkan pendidikan ke Singapura atau ke Makkah. Sudah barang tentu Hasan Maksum memilih untuk belajar ke Makkah dibandingkan dengan Singapura dengan pertimbangan bahwa Sumatera Timur masih membutuhkan ulama. ${ }^{13} \mathrm{Hal}$ ini menggambarkan bahwa Hasan Maksum, memiliki keterampilan dalam berbahasa asing baik Inggris maupun Arab. Bahasa Inggris diperolehnya melalui pendidikan formal, sedangkan Bahasa Arab dikuasai semasa mengikuti pengajian agama di sore hari. ${ }^{14}$

Memasuki usia sepuluh tahun (1894), ${ }^{15}$ Hasan Maksum melanjutkan pendidikannya ke Makkah dengan mengikuti rombongan Jamaah Haji yang akan berangkat ke tanah suci. Karena berangkatnya bersamaan dengan rombongan jamaah haji sudah tentu ramai orang yang mengantarkan di pelabuhan Belawan, hingga sampai ke Titi Papan. Riuhrendah suara tangis dan lantunan suara azan mengiringi kepergian Hasan Maksum dalam menuntut ilmu ke tanah suci. Perjalanan yang begitu melelahkan itu dilalui walau harus mengorbankan nyawa sebagai taruhannya dalam mengarungi gelombang sebesar gunung di samudra yang luas. Perjalanan dari tanah air menuju tanah suci seabad yang lalu bukan perkara mudah, di samping keterbatasan transportasi juga harus memakan biaya yang besar dikarenakan lamanya perjalanan yang mencapai waktu tiga bulan. ${ }^{16}$

Hasan Maksum, menjadi murid dari beberapa ulama besar di kota Makkah pada tahun 1875, di antaranya adalah sebagai berikut:

(1) Ahmad Khatib al-Minangkabawi, 17 berasal dari Maninjau. Ulama yang cukup disegani karena kealimannya, beliau diangkat oleh penguasa Makkah, Syarif Husain menjadi ulama Imam Syafi'i di Masjidil Haram dan kemudian diangkat pula menjadi Mufti Kerajaan, suatu jabatan tertinggi yang pernah ditempati oleh putra Indonesia; (2) Abdussalam Kampar, seorang ulama yang berasal dari Kampar; (3) Ahmad Khayath, seorang ulama ternama dari bangsa Arab; (4) Ali Maliki, seorang ulama ahli Naḥwu yang terkenal dengan "Zamawi" (ahli Naḥwu

12 Tengku Luckman Sinar, Sejarah Medan Tempo Doeloe (Medan: Perwira, 2007), h. 86.

${ }^{13}$ Mona, Riwajat Penghidoepan, h. 8.

${ }_{14}$ Ja'far, Biografi Intelektual Ulama-Ulama Al Washliyah (Medan: Centre for $\mathrm{Al}$ Washliyah Studies, 2012), h. 14-15.

${ }^{15}$ Ibid., h. 15.

${ }^{16}$ Institut Agama Islam Negeri al-Jamiah Sumatera Utara, Sejarah Ulama, h. 8-9.

17 Ahmad Khatib al-Minangkabawi, adalah guru utama dari Hasan Maksum ketika belajar di Makkah al-Mukaramah. Lihat: Maksum, Biografi Alm., h. 1. 
zaman ini); (5) Saleh Baffadhil; (6) Amin Ridwan, di Madinah berasal dari Minangkabau juga;18 (7) Abdul Hamid Kuddus; (8) Usman Tanjungpura; (9) Abdul Karim al-Mandili; (10) Sa'id Jamani; dan (11) Abdul Karim Dadhastany. ${ }^{19}$

Nama-nama ulama di atas dikenal di seluruh Nusantara, banyak ulama yang menuntut ilmu kepada mereka selama berada di tanah suci. Dari nama-nama tersebut, Hasan Maksum belajar secara tekun selama sembilan tahun. Berbagai macam disiplin keilmuan dipelajarinya, mulai dari Tafsir, Fikih, Bahasa Arab, Tasawuf, Naḥwu, Șarf, dan lain sebagainya, baik ketika berada di Makkah maupun Madinah. Proses pembelajaran dilakukan siang dan malam, sehingga menjadikan Hasan Maksum lupa waktu ketika sedang berhadapan dengan buku yang dipegangya. Sehingga gurunya merasa yakin bahwa Hasan Maksum kelak akan menjadi ulama besar di Indonesia. ${ }^{20}$

Sembilan tahun dalam menuntut ilmu bukan merupakan waktu yang sebentar, tidak hanya sekedar kenyang dengan ilmu pengetahuan beliau juga memiliki kenalan yang luas selama menuntut ilmu di Makkah. Banyak pelajar-pelajar yang datang menuntut ilmu bersamanya baik dari Sumatera maupun Jawa, di antara mereka adalah ulama-ulama masyhur di tanah air, sebagian mereka adalah:

(1) Abdul Karim; (2) Abdul Majid; (3) Musthafa Husein Purba Baru; (4) Abdul Qadir al-Mandili; dan (5) Muhammad Dahlan, yang ketika itu juga terhitung sebagai seorang ulama di Makkah. Banyak perubahan yang terjadi baik di tanah suci maupun di tanah air dalam masa itu, beberapa kali keluarganya meminta agar Hasan Maksum kembali ke tanah air, apalagi setelah ibu kandungnya meninggal dunia tanpa kehadirannya. Dengan berat hati akhirnya pada tahun 1903 Hasan Maksum terpaksa meninggalkan tanah suci untuk kembali ke tanah air. ${ }^{21}$

Sebagai seorang ulama, aktivitas belajar dan mengajar dilakukan mulai pada saat berada di Mekkah - mengajar di rumahnya sendiri di daerah Syamiyah - sampai setetelah kembali ke tanah air beliau mengajar di Medan pada beberapa tempat baik di rumah, madrasah, beberapa masjid seperti: Masjid Raya al-Mashun Medan, Masjid gang Bengkok Kewasan Medan, Masjid Kampung Percut, Masjid Kampung Bandar Setia, dan Masjid Bagan Deli. ${ }^{22}$ Selain aktivitas belajar dan mengajar beliau juga merupakan pejabat pemerintahan pada masa Kesultanan Deli, dengan jabatan 'Pemeriksa Ujian'. Pemeriksa ujian kalau saat ini mungkin setingkat pengawas bagi para guru, beliau melakukan pengujian pada

\footnotetext{
${ }^{18}$ Institut Agama Islam Negeri al-Jamiah Sumatera Utara, Sejarah Ulama, h. 10.

${ }^{19}$ Maksum, Biografi Alm., h. 1.

${ }^{20}$ Institut Agama Islam Negeri al-Jamiah Sumatera Utara, Sejarah Ulama, h. 10-11.

${ }^{21}$ Ibid., h. 11.

22 Maksum, Biografi Alm., h. 1,
} 
orang yang akan diangkat menjadi Kadhi wilayah Kesultanan Deli. Selain itu beliau juga menjabat sebagai Advisior di Landraad dalam bagian Hukum-hukum Islam dan Advisior Mahkamah Kerapatan Sultan Deli dalam Bagian Hukum-hukum Islam. ${ }^{23}$

Karangan-karangan Hasan Maksum, sangat susah ditemukan di perpustakaan baik di kota Medan maupun di Sumatera Utara secara umum. Belakangan diketahui bahwa sebagian karya Hasan Maksum, telah disimpan di Perpustakaan Universitas Brunei Darussalam, antara lain: Samir as-Sibyan li Ma'rifah Furuḍ al-'Ayan dan Risālah Tażkir al-Muridìn fi Sulük Tariqah al-Muhtadīn. Kedua karya ini diterbitkan oleh penerbit Mațba'ah Mușțafa al-Bābi al-Halābi wa Aulādah bi Mishr pada tahun 1934. ${ }^{24}$ Walaupun keberadaan karangan Hasan Maksum, di negeri orang ini patut dinilai sebagai suatu hal yang positif yaitu bahwa karya-karya beliau ini sangat diminati sampai ke mancanegera tentunya akan sedikit menghibur. Namun sedikit banyak akan berdampak sebaliknya yaitu ada juga hal negatifnya bahwa sampai saat ini tidak ditemukan teks asli maupun salinannya di Indonesia. Bahkan menurut Ja'far, "karya tersebut terus dikaji oleh sejumlah ulama di Malaysia." 25

Sebagai seorang ulama yang memiliki ilmu yang luas, dikenal sepanjang hayatnya sudah tentu akan melahirkan ulama-ulama yang akan mewariskan khazanah keilmuannya. Di antara ribuan muridnya yang tidak dapat didata satu per satu baik saat beliau berada di Makkah maupun setelah kembali ke tanah air, beberapa muridnya yang terkemuka adalah sebagai berikut:

1) Muhammad Yunus, guru Maktab Islamiyah; 2) Abd. Malik, guru Maktab al-Falah Sukaraja dan anggota Pengurus Besar al-Ittihadiyah; 3) Abd. Rahman Syihab, ketua Pengurus Besar Al Jam'iyatul Washliyah; 4) M. Baharuddin Thalib, di Sibolga; 5) Muhammad Arsyad Thalib Lubis, Pengurus Besar Al Jam'iyatul Washliyah di Medan; 6) Abd. Rauf, orang tua dari al-Hafiz Azrai Abd. Rauf Gelugur; 7) Suhailuddin, di Rantau Perapat; 8) Ilyas, Kadhi Kampung Baru Medan; 9) Zakaria Abd. Wahab, Jalan Serdang; 10) Ali Usman, Jalan Padang Bulan bertoko di Kesawan; 11) Kudin, orang tua Jamaluddin Lubuk Pakam; 12) Saleh, Muballiq terkenal Pengurus Besar al-Ittihadiyah; 13) M. Yusuf, Sei Mati toko kitab di Pasar Ikan Lama; 14) Mahmud Abu Bakar, Pengurus Besar al-Ittihadiyah; dan Zainal Arifin Abbas, Pengurus Besar al-Ittihadiyah. ${ }^{26}$

Namun perjuangannya dalam mencerdaskan masyarakat dan membesarkan nama Al Jam'iyatul Washliyah harus berakhir. Pada usia 53

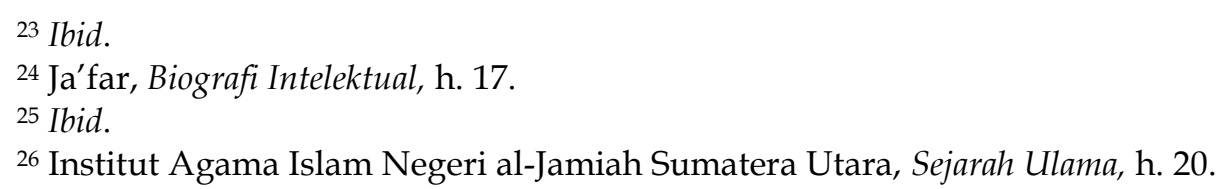


tahun Hasan Maksum mengakhiri karirnya baik sebagai Mufti di Kesultanan Deli dan sebagai guru besar di Sumatera Utara ketika Yang Maha Kuasa memanggilnya kembali ke alam yang abadi. "Sakit yang dialaminya berdasarkan analisis dokter yang merawatnya karena urat yang menghubungkan ke otaknya telah tertutup, sebab terlalu banyak membaca (studie) yang melewati kemampuan urat di mata dan otak itu."27

Meninggalnya Hasan Maksum, merupakan suatu kehilangan yang sangat besar tidak hanya bagi masyarakat Sumatera Utara akan tetapi dunia Islam pada umumnya. Sebagai ulama besar, kabar meninggalnya dalam waktu singkat tersebar di seluruh kota, maka umat Islam dan murid-muridnya merasakan duka cita yang sangat dalam. Kondisi berduka dapat dirasakan oleh masyarakat hal itu dapat terlihat:

"Pada hari itu umat Islam yang terdiri dari para guru, murid haji, lebai, kaya dan miskin, pejabat dan segala lapisan masyarakat baik yang dekat maupun jauh berkumpul untuk menunjukkan bela sungkawa. Ribuan orang hadir di rumah beliau, berebut untuk menyaksikan ulama besar ini untuk terakhir kalinya. Bukan hanya sekedar ta'ziah tapi berebut pula menggali kuburan sebagai tempat peristirahatan terakhir sang 'Paduka Tuan' sebagai cinta dan kasih yang terakhir berhidmat kepada guru yang dihormati." 28

Jumlah pelayat hadir untuk mengantarkan kepulangan Hasan Maksum kehadapan Yang Maha Kuasa menggambarkan bahwa keulamaannya, dikenal luas di kota Medan khususnya Sumatera Utara umumnya. Hal ini dapat dilihat dengan antusiusnya masyarakat kota Medan dalam menimba ilmu kepada beliau semasa hidupnya. Maka tidak salah jika ulama besar Syekh Abdul Qadir di Makkah ketika berkunjung ke Deli, mengatakan bahwa: "Deli ini telah kejatuhan sebutir bintang yang gilang-gemilang, akan tetapi penduduk belum mengetahuinya. Tambah lama bintang Zuhra akan bertambah memancarkan sinarnya dan mudahmudahan dapatlah kerajaan Deli ini seorang pujangga Islam yang jarang didapati." 29

\section{Kontribusi dalam Dunia Pendidikan}

Kontribusi Hasan Maksum dalam dunia pendidikan sudah terlihat dari riwayat pendidikannya. Sebagai seorang pelajar yang giat, sudah tentu beliau juga memiliki cita-cita besar bagi bangsa dan negaranya. Hasan Maksum lebih memilih melanjutkan pendidikannya ke Tanah Suci Makkah dibandingkan dengan belajar di Singapura yang sudah lebih maju pendidikan sainsnya. Pilihan untuk belajar di Makkah merupakan cita-cita yang sudah tertanam dalam dirinya untuk memperbaiki

\footnotetext{
${ }_{27}$ Mona, Riwajat Penghidoepan, h. 6.

28 Ibid.

${ }^{29}$ Institut Agama Islam Negeri al-Jamiah Sumatera Utara, Sejarah Ulama, h. 15.
} 
pemahaman keagamaan masyarakat Labuhan Deli ketika itu. Kehidupan masyarakat Labuhan Deli masih jauh dari ajaran Islam, bahkan masih banyak yang belum mengenal agama sama sekali. Masyarakat masih banyak yang menganut agama Parbegu ${ }^{30}$ atau sebagai Hindu dan Ciwa. ${ }^{31}$

Kembalinya Hasan Maksum dari Makkah setelah menimba ilmu selama 20 tahun dan menjadi guru di Masjid al-Haram, tidak serta merta menjadikannya dikenal oleh masyarakat luas. Meskipun sudah menjadi ulama terkemuka di Masjid al-Haram, Hasan Maksum tetap menjalani kehidupan zuhud dan tidak menyukai popularitas. ${ }^{32}$ Pengaruh besarnya selama menjadi guru di Masjid al-Haram tidak diketahui oleh masyarakat Labuhan Deli yang disibukkan dengan urusan duniawi.

Setelah beliau mengajar di Titi Papan dan mendapatkan sambutan yang baik dari masyarakat yang ingin menuntut ilmu, akhirnya beliau memutuskan untuk pindah ke Medan. Di Medan beliau mulai dikenal dan memiliki banyak murid yang datang dari berbagai daerah. ${ }^{33}$ Pendidikan agama Islam masih bersifat pengajian yang dilaksanakan di rumah-rumah tuan guru, langgar maupun masjid. Dalam kondisi ini Hasan Maksum sudah memiliki ribuan murid yang berasal dari berbagai daerah di Sumatera Timur. Bertahun-tahun beliau menjadi guru besar dan setiap harinya selalu diisi dengan pengajian. Pengajian dipusatkan di langgar miliknya dan masjid Raya al-Mahsun Medan, pengajian ini selalu menjadi pusat perhatian para penuntut ilmu yang terdiri dari orang tua maupun anak muda. ${ }^{34}$

Kondisi Sumatera Timur waktu itu memang sangat membutuhkan seorang ulama dan lembaga-lembaga pendidikan yang bisa memberikan pemahaman keagamaan terhadap masyarakat sekitarnya. Hal ini dapat dilihat dari kesungguhan para murid yang datang belajar kepada Hasan Maksum, yang mana ketika itu pusat pengajiannya difokuskan di langgar miliknya yang sekarang dikenal dengan Mushalla Hasan Maksum di Jalan Puri dan Masjid Raya al-Mahsun Medan.

Hasan Maksum, salah seorang ulama yang bersinar pada tahun 1915 di Tanah Deli, 35 tidak sedikit murid-muridnya menjadi ulama besar seperti dirinya. Di samping tugas formalnya sebagai seorang Mufti Sultan Deli di Medan, beliau tetap memprioritaskan diri dengan kegiatan belajar mengajar, mengasuh sejumlah murid dan mengajarkan mereka beberapa

30 Perbegu juga dikenal sebagai Pelebegu yang merupakan paham animisme di Tanah Karo, sedangkan Begu berarti Hantu Hutan. Lihat: Tim Penyusun Kamus Pusat Bahasa, Kamus Besar Bahasa Indonesia, Edisi ke-4 (Jakarta: Pusat Bahasa, 2008), h. 158.

${ }^{31}$ Mona, Riwajat Penghidoepan, h. 8.

32 Ja'far, "Tarekat dan Gerakan, h. 283.

${ }^{33}$ Mona, Riwajat Penghidoepan, h. 20.

34 Ibid., h. 7.

35 Ja'far, Biografi Intelektual, h. 15. 
disiplin keilmuan di antaranya adalah Tafsìr Jalālain karya Jalāl ad-Dīn asSuyūṭi dan Jalāl ad-Dīn al-Maḥalli, Fath al-Mubìn: Syarh Matn al-'Arba'ìn karya Ibnu Hajar al-Haitami, Șahīh al-Bukhāri karya Imam Bukhāri, Syarh Jam'u al-Jawami' Syarḥ Waraqat karya Jalāl ad-Dīn al-Maḥalli, dan Minhaj ațTalibin karya an-Nawawi. ${ }^{36}$

Hasan Maksum, mengajarkan buku-buku tersebut karena beliau memiliki sanad keilmuan yang terhubung langsung dari para gurunya sampai kepada penulis kitab-kitab tersebut selama menuntut ilmu di Tanah Suci Makkah (periode pertama tahun 1894-1906 dan peiode kedua tahun 1907-1915). ${ }^{37}$ Beliau membaca dan memahami kitab-kitab tersebut selama belajar bersama gurunya yang merupakan ulama-ulama bermazhab Syafi'i yang masyhur ketika itu. ${ }^{38}$ Beliau dikenal sebagai seorang ulama besar yang senantiasa menjaga linieritas keilmuan yang diperolehnya ketika belajar di Makkah, selanjutnya ilmu itu pula yang dikembangkannya di tengah-tengah masyarakat.

Hasan Maksum, merupakan guru bagi para ulama Sumatera Timur dan pendiri Al Jam'iyatul Washliyah baik secara formal maupun nonformal. Di antara ribuan muridnya ada beberapa nama besar yang kemudian dikenal di Al Jam'iyatul Washliyah di antaranya adalah Mahmud Ismail Lubis (1900-1937), Adnan Lubis (1910-1966), Azra'i Abdurrauf, Yusuf Ahmad Lubis (1912-1980) dan muridnya yang paling terkenal adalah Muhammad Arsyad Thalib Lubis (1908-1972), salah seorang pendiri Al Jam'iyatul Washliyah yang berhasil membesarkan nama organisasi ini ${ }^{39}$ dengan berbagai kemampuan yang dimilikinya.

Apa yang didapatkan oleh para murid ini selanjutnya dikembangkan di tengah-tengah masyarakat, Di antara sekian banyak murid tersebut hanya sebagian kecil saja yang bergabung dengan organisasi Al Jam'iyatul Washliyah yang diasuh oleh Hasan Maksum. Sebagian besar murid yang lain memilih untuk mengembangkan ilmu yang diperolehnya dengan cara sendiri-sendiri dan tidak bergabung dengan organisasi manapun. Kondisi ini terjadi karena tidak semua murid-murid Hasan Maksum tersebut yang berpikiran untuk memajukan masyarakat banyak, namun lebih kepada mementingkan diri sendiri. ${ }^{40}$ Tidak semua murid yang pernah belajar kepada Hasan Maksum tertarik untuk berorganisasi atau menjadi guru, banyak di antara mereka yang melanjutkan karir yang berbeda.

Setelah wafatnya Hasan Maksum, tradisi ini dilanjutkan oleh muridnya yang paling terkenal keilmuannya bahkan dikenal sebagai

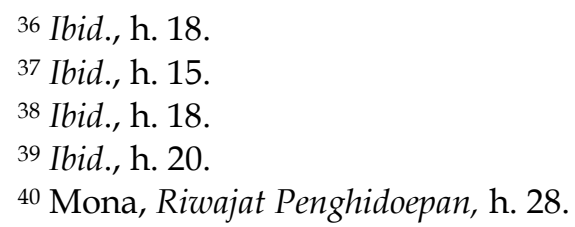


Kristolog dari Sumatera, yaitu Muhammad Arsyad Thalib Lubis. Tidak hanya sekedar mengajar di pengajian-pengajian atau pada pendidikan non-formal, bahkan sebelum kemerdekaan Indonesia pada tahun 1931 beliau telah mengajar di sejumlah madrasah seperti Madrasah alIrsyadiyah dan madrasah Al Jam'iyatul Washliyah Lhokseumawe. Pada tahun 1940 Al Jam'iyatul Washliyah mendirikan madrasah al-Qismul Ali, beliau menjadi pimpinan serta guru di madrasah tersebut. ${ }^{41}$ Muhammad Arsyad Thalib Lubis mengajar banyak bidang seperti Fikih, Ushul Fikih, Tasawuf, Retorika, al-Adyan dan Tafsir. Selain itu juga terdapat namanama besar beberapa murid Hasan Maksum lainnya yang mengajar di madrasah ini, seperti Adnan Lubis sebagai guru Hadits, dan Zainal Arifin Abbas mengajarkan sejarah Islam. ${ }^{42}$

\section{PENUTUP}

Hasan Maksum adalah seorang ulama besar di Sumatera Utara, kharismatik, memiliki ilmu yang cukup luas, aktif dalam berbagai aspek kehidupan sosial, politikus yang disegani, memiliki ribuan murid yang tersebar di daerah ini. Kontribusi Hasan Maksum dalam dunia pendidikan sampai hari ini masih dirasakan oleh masyarakat Sumatera Utara khususnya dan Indonesia pada umumnya. Beliau juga dikenal sebagai guru dari ulama-ulama besar di Sumatera Utara. Dalam bidang sosial beliau menjadi penasehat dua organisasi besar di Sumatera Utara yaitu Al Jam'iyatul Washliyah dan Al-Ittihadiyah, hal ini dikarenakan kedua organisasi ini berpegang pada mazhab Syafi'i.

\section{DAFTAR PUSTAKA}

Institut Agama Islam Negeri al-Jamiah Sumatera Utara. Sejarah UlamaUlama Terkemuka di Sumatera Utara. Medan: Islamyah, 1975.

Ja'far. "Tarekat dan Gerakan Sosial Keagamaan Shaykh Hasan Maksum." Teosofi: Jurnal Tasawuf dan Pemikiran Islam Vol. 5, no. No. 2 (2015).

Ja'far. Biografi Intelektual Ulama-Ulama Al Washliyah. Medan: Centre for Al Washliyah Studies, 2012.

Lubis, M. Ridwan Ibrahim. Kepribadian Anggota \& Pengurus Al Washliyah. Medan: PP HIMMAH, 1994.

Maksum, Ahmad bin Hasan. "Biografi Almarhum Syech Hasanuddin Maksum." Makalah tidak diterbitkan.

Mona, Matu. Riwajat Penghidoepan Alfadil: Toen Sjech Hasan Ma'soem (Biografi Sedjak Ketjil sampai Wafatnja). Medan: Sjarikat Tapanoeli Medan, tanpa tahun.

\footnotetext{
41 Ja'far, Biografi Intelektual, h. 60-61.

42 Ibid., h. 61.
} 
Rozali, Muhammad. Tradisi Keulamaan Al Jam'iyatul Washliyah Sumatera Utara. Yogyakarta: LKiS, 2017.

Sinar, Tengku Luckman. Sejarah Medan Tempo Doeloe. Medan: Perwira, 2007.

Suryanegara, Ahmad Mansur. Menemukan Sejarah Wacana Pergerakan Islam di Indonesia . Bandung: Mizan, 1995.

Tim Penyusun Kamus Pusat Bahasa. Kamus Besar Bahasa Indonesia. Edisi ke4. Jakarta: Pusat Bahasa, 2008. 